\title{
Relationship between market discipline and capital buffers in Brazilian banks ${ }^{*, * *}$
}

\author{
José Alves de Carvalho ${ }^{1}$ \\ (D) https://orcid.org/0000-0002-4148-1790 \\ Email: josecarvalho.leader@gmail.com \\ José Alves Dantas ${ }^{1}$ \\ (iD) https://orcid.org/0000-0002-0577-7340 \\ Email: josealvesdantas@unb.br
} ${ }^{1}$ Universidade de Brasília, Faculdade de Economia, Administração, Contabilidade e Gestão Pública, Departamento de Ciências Contábeis
e Atuariais, Brasília, DF, Brazil

Received on 08.15.2019 - Desk acceptance on 09.10.2019 - $3^{\text {rd }}$ version approved on 04.11.2020

Editor-in-Chief: Fábio Frezatti

Associate Editor: Fernanda Finotti Cordeiro

\begin{abstract}
The aim of this study was to investigate the relationship between the market discipline and the capital buffers of Brazilian banks, identifying the channels through which this phenomenon materializes. The literature on market discipline and capital buffers has focused on developed countries. In Brazil, the topic is in its infancy, despite the characteristics of the market representing a relevant opportunity for broadening the related studies. Even with the specificities of an emerging market, the Brazilian banking industry provides a vast field for studying market discipline and capital buffers, given that the banks have leverage with investors, who are sensitive agents to alterations in the risk appetite of those entities. This study contributes to understanding the dynamics of the market discipline in the banking industry and to fostering discussions about the role of that private supervision in promoting the transparency and solidity of the financial system, providing support and guidelines for banking regulation. Using data from 193 Brazilian banks, from 2001 to 2017, the empirical tests included the estimation of panel data models, with the use of two-stage least squares (TSLS), following Ayuso et al. (2004), Flannery and Rangan (2004), and Nier and Baumann (2006). As the discipline exercised by the monitoring and influence of the market is not directly verifiable by external agents, six proxies were developed based on the cost of fundraising, on unsecured deposits, on subordinated debt, and on disclosure. The capital buffer was represented by the difference between the capital calculated by the institution and the minimum regulatory requirement. The results of the empirical tests revealed a positive association between the capital buffer and market discipline, providing evidence of the presence of that private supervision in the Brazilian banking industry.
\end{abstract}

Keywords: market discipline, banks, disclosure, capital buffer.

Correspondence address

José Alves de Carvalho

Universidade de Brasília, Faculdade de Economia, Administração, Contabilidade e Gestão Pública, Departamento de Ciências Contábeis e Atuariais

Campus Universitário Darcy Ribeiro, Bloco A-2, 1º andar - CEP 70910-900

Asa Norte - Brasília - DF - Brasil

* Article presented at the XIX USP International Conference in Accounting, São Paulo, SP, Brazil, July of 2019.

** The authors are grateful to professors Dr. Jorge Katsumi Niyama and Dr. Joshua Onome Imoniana, who participated on the master's board, to the evaluators and participants of the XIX USP International Conference in Accounting, and to the blind review evaluators of the Accounting \& Finance Review (RC\&F), who contributed with their questions to improving the study. 


\section{INTRODUCTION}

Antecedents of market discipline date back to the 1970s (Barth et al., 2004; Bertay et al., 2013; Bliss \& Flannery, 2001; Elyasiani \& Keegan, 2017; Flannery \& Nikolova, 2003; Flannery \& Sorescu, 1996; Gilbert, 1990; Scott, 2014), but the classic literature highlights that there has been little empirical evidence about the influence of the market, given the difficulty of identifying the effectiveness of that mechanism in the banking industry.

Within that context, the capital requirement has become the most used instrument by the regulations, through the Basel I, II, and III Accords. Only in Basel II (Basel Committee on Banking Supervision [BCBS], 2006), was market discipline (Pillar 3) formally included in the banking regulations in a complementary way to the minimum capital requirements (Pillar I) and to the supervisory review process (Pillar 2). In Basel III (BCBS, 2011), the new disclosure requirements of Pillar 3 were consolidated.

The literature on buffers, in turn, highlights that banks hold capital above the regulatory minimum for various reasons, such as maintaining the value of the bank charter and avoiding high capital adjustment costs, indicating market discipline as the first motivation (Fonseca \& González, 2010). In the international arena, there are studies that mostly focus on the positive relationship between market discipline and capital buffers (Ayuso et al., 2004; Bouther \& Francis, 2017; Distinguin \& Rugenmintwari, 2012; Fonseca \& González, 2010; Nier \& Bauman, 2006). In the Brazilian literature, although other papers have studied the effects and the determinants of capital buffers - such as those of Belém and Gartner (2016), Pinheiro et al. (2015), and Tabak et al. (2011, 2013) - the studies relating market discipline and capital buffers are in their infancy, among which that of Silva and Divino (2012) stands out, who used a dynamic panel model for the purposes of identifying the persistence of excess capital. Even with the specificities of an emerging economy, such as an important part of the deposits being insured by the Credit Guarantee Fund (FGC), the Brazilian banking industry provides a vast field for studying market discipline more extensively, given that the banks have leverage with debtholders, which makes the interested parties sensitive to alterations in the risk appetite of those entities.

Given that gap of empirical studies in the national banking industry, the present study aims to investigate the relationship between market discipline and capital buffers in Brazilian banks. The premise considered is that the banks react to the discipinary effect of the market regarding risk exposure by reinforcing capital, configuring a positive relationship between capital buffers and market discipline.

In line with the international findings, the study aims to improve the understanding of the dynamics of market discipline in Brazil and to foster empirical discussions around the role of that private supervision in promoting the transparency and solidity of the financial system, as well as providing support to policymakers for formulating policies and guidelines for bank regulations, given their alignment with both Basel II and Basel III.

\section{THEORETICAL FRAMEWORK}

\subsection{Capital Requirement and Basel Ratio}

Given the peculiarities of banks, the main motivation of the prudential regulations is to maintain the stability of the financial system. Since the creation of the Basel Committee on Banking Supervision (BCBS), in 1974, the regulations have evolved with the so-called Basel I, II, and II Accords (BCBS, 2018), especially with the establishment of minimum capital requirements. In accordance with the recommendations of the BCBS, the National Monetary Council (CMN) established operational limits to be observed by the financial institutions in the Brazilian market. In the last agreement, the alignment occurred via CMN Regulation n. 4,192/2013.
However, although capital requirements have become the most used instrument to protect the financial system against unexpected losses, empirical studies report holes in their efficiency (Scott, 2014; Tarullo, 2008), emphasizing that the reforms presented by Basel II have brought more capital constraints. In this sense, Dewatripont and Tirole (1994) record that regulatory capital has worked as a type of deposit insurance, inducing greater risk taking by banks and leading them to assume more risks in an attempt to achieve a particular target return.

Seeking the security of the banking system, and in response to the 2007/2008 financial crisis, Basel III introduced capital reinforcement mechanisms, defined as the conservation and systemic risk capital in additional 
to the core capital, instituted to protect against financial difficulties of the institutions at times of stress and to reduce the impact of the collapse of institutions that are systemically important for the economy, respectively. It also introduced the countercyclical buffer, which acts as a macroprudential measure to protect the banking sector in periods of excess growth of aggregate credit (BCBS, 2011).

In the specific case of the countercyclical buffer, the Central Bank of Brazil (BC), through its Financial Stability Report (BC, 2018), reports that countries such as Slovakia, Hong Kong, Iceland, Norway, the Czech Republic, and Sweden already have additional capital requirements in effect, while others, such as Denmark, Lithuania, and the United Kingdom, have announced the requirement at a future date. In Brazil, BC Circular Letter n. 3,769/2015 set at $0 \%$ the additional countercyclical capital value assumed by the financial institutions, which stayed at that threshold until the end of the period considered in this study.

\subsection{Market Discipline}

Flannery (2001) highlights that, despite the term market discipline having become popular in the eyes of academics, banks, and supervisors, the exact meaning of the term has continued to be imprecise and lacking any clear meaning. In light of that, Bliss and Flannery (2001) defined the conceptual structure of market discipline according to Figure 1.

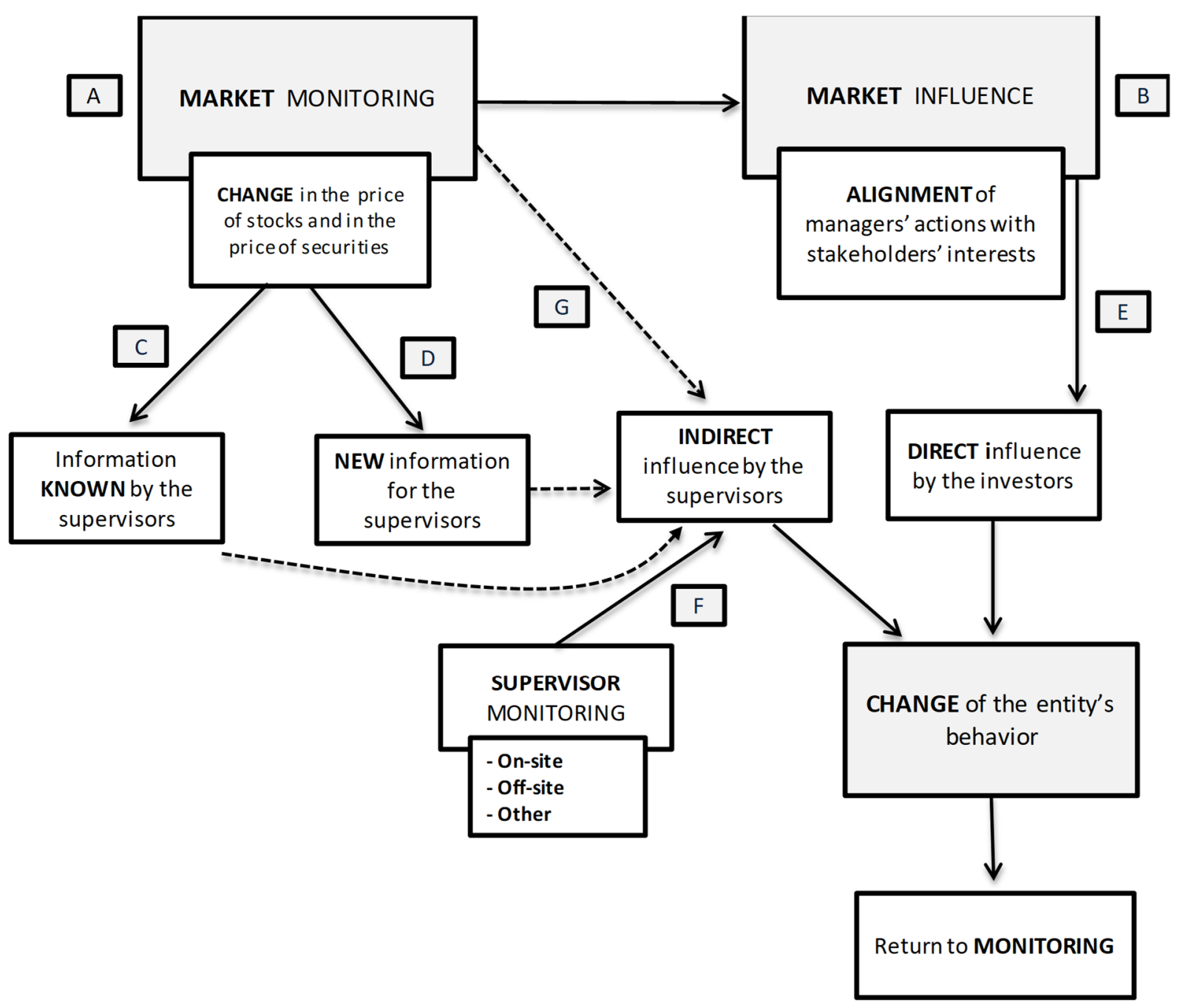

Figure 1 Anatomy of market discipline

Source: Adapted from Bliss \& Flannery (2001) 
For Bliss and Flannery (2001), market discipline includes two different components:

a) Market monitoring: this refers to the hypothesis that investors accurately evaluate the changes in a bank's conditions and incorporate them into the prices of the stocks and securities of the financial institution (point A of Figure 1). The monitoring generates signs that can convey useful information to the supervisors.

b) Market influence: the process by which the external claims influence the behavior of the financial institution's administrators, represented by point B of Figure 1.

The dynamics present in market discipline is one where some worsening of a bank's risk identified in the market monitoring leads investors to take measures seeking to reduce the level of exposure, whether by raising the cost of financing or reducing the volume of new business. The market's influence makes banks align their actions, acting to avoid higher costs that may be demanded by the market participants in the future. For Nier and Baumann (2006), ex ante market discipline encourages better risk and capital management by banks. For the regulator, the market information may shorten the time interval for supervisory action for banks in financial difficulties (Flannery, 1998).

Although there is vast international literature on the topic, concentrating on the North American banking industry [Barth et al. (2004), Bertay et al. (2013), Bliss \& Flannery (2001), Elyasiani \& Keegan (2017), Flannery \& Nikolova (2003), Flannery \& Sorescu (1996), Gilbert (1990), and Scott (2014), for example], the market discipline phenomenon is not simply verifiable by external agents, which imposes the use of proxies to characterize it, such as spreads on securities, the cost and volume of unsecured deposits, and subordinated debt, among others.

Within the scope of prudential regulation, market discipline was only recognized in Basel II (BCBS, 2006), in a complementary way to the minimum capital requirements and to supervisory review. It was reinforced in Basel III (BCBS, 2011), which introduced and consolidated new disclosure requirements.

Consistently with the regulatory incentives, Nieto (2012) highlights that the materialization of market discipline depends on at least three conditions: the existence of adequate and timely information about the risk profiles of the banks, through adequate disclosure; the creditors considering themselves at risk; and the reaction to the market signs being observable.
As a limit to the strength of market discipline, Nier and Baumann (2006) mention government guarantees in the form of secured liabilities. The underlying premise is that the insurance creates an incentive for banks to assume greater risks, configuring moral hazard. According to Gilbert (1990), without deposit insurance, banks that have chosen asset portfolios with a higher variance, or lower capital ratios, would have to pay higher interest rates in new fundraising, which would not occur if most of the deposits were insured.

\subsection{Market Discipline and Capital Buffer}

Given the regulatory appeal, banks are expected to present capital above the regulatory requirement (Flannery \& Rangan, 2004). However, as the obtainment of capital is related to the costs in time and effort, which is consistent with the theory of the hierarchy of sources of financing, known as the pecking order, in which the capital structure results from the decisions about the sources of financing in an ordered way (self-financing versus external financing, payout reductions, retained earnings versus issuing new stocks), Fonseca and González (2010) indicate market discipline as the first motivation of banks for maintaining a capital buffer above the regulatory minimum.

Regarding the relationship between market discipline and capital buffers, Tarullo (2008) affirms that it can be accepted that capital requirements are positively correlated with market discipline and supervisory reinforement, although he identifies that the effects of the capital caused by market discipline requires further investigation. Along the same lines, Nier and Baumann (2006) highlight that, in the presence of the market discipline represented by unsecured liabilities and a greater level of disclosure, banks are led to maintain higher capital buffers. So, if there is market discipline, the choice of capital for a particular additional risk exposure will probably by efficient. However, when market discipline is weak, the banks' capital buffers will tend to be inefficiently low.

In the same sense, Fonseca and González (2010) state that depositors may demand higher returns to offset the excessive risk taking of the banks in an environment in which liabilities are not totally secured. With that, managers may be incentivized to raise their capital, seeking to minimize the bank risk and reduce the cost of new fundraising. The authors found evidence that capital buffers are positively related to the cost of deposits, although that relationship varies according to the country, depending on the local regulations and supervision.

For Distinguin and Rugemintwari (2012), the presence of debt securities in the financing of banks drives the existence of capital above the regulatory level. Investors, 
known as debtholders, may not have confidence in the survival capacity of the institutions that are operating with a capital ratio close to the regulatory minimum. If this occurs, they will pressure them to raise the capital level or target.

In the Brazilian banking industry, Silva and Divino (2012) analyzed the persistence of the excess capital in the system, using the lagged capital variable, revealing the presence of market discipline through external investors, who demand a higher risk premium from the banks perceived as being riskier. They found that, in response to the increase in fundraising costs, the banks raise their share of own capital. Other studies have evaluated the effects or determinants of capital buffers, although they have not specifically focused on the relationship with market discipline, such as: Tabak et al. (2011), who found a negative relationship between economic cycles and excess capital; Tabak et al. (2013), who verified the positive impact of capital buffers on the profitability of Brazilian banks; Pinheiro et al. (2015), who concluded that the implementation of the Basel III capital requirements should intensify the search for efficiency and profitability; and Belém and Gartner (2016), who found that the adjustment and bankruptcy costs are relevant for explaining the capital buffer, while the cost of maintaining the capital did not present statistical significance.

For Scott (2014), under direct market influence, debt security holders charge for the increased risk of the financial institution through more expensive fundraising, used to fund asset operations, serving as an indicator for disciplining capital management, as management is incentivized to minimize the costs of financing. Given that the capital requirement serves as a risk mitigator for banks, it performs a crucial role in aligning managers' incentives with depositors and other creditors (Berger et al., 1995; Keeley \& Furlong, 1990). Due to this, Nier and Baumann (2006) point to the need to analyze market discipline relative to changes in banks' behavior, via the capital buffer, in an attempt to avoid the market imposing higher spread costs. That ex ante discipline serves to encourage the entities in terms of prudent risk management.

Along the same lines, Bouther and Francis (2017) highlight that, for certain exposures to market discipline, banks seek higher capital ratios for riskier assets, consistent with the existence of the ex ante disciplinary effect regarding the risk taking behavior of banks. The presence of a positive association between unsecured debt and the capital ratio is explained by the institution's capacity to access the short-term unsecured financing market being made easier if it is better capitalized.

The enforcement generated by Basel II and III in the supervisory review process is also noted, in which the regulators note: the expectation that banks will operate with a capital level above the regulatory minimum; that market discipline complements minimum capital requirements; the capital requirements for covering relevant risks.

Given this context, and considering the role of market discipline in the accumulated capital buffer, the following hypothesis is formulated, to be empirically tested:

$\mathrm{H}_{1}$ : the capital buffer of Brazilian banks is positively related with the market discipline, configuring the direct (ex ante) disciplinary effect over the banks' risk taking behavior.

\section{METHODOLOGY}

To carry out the empirical tests of research hypothesis $\mathrm{H}_{1}$, this section defines the econometric model to be applied, including the definition and detailing of the effects of the market discipline proxies.

\subsection{Definition of the Model}

To structure the model enabling the research hypothesis to be tested, the first step consists of defining the capital buffer variable. According to Distinguin and Rugemintwari (2012), excess capital is represented by the difference between the capital calculated by the institution and the minimum regulatory requirement, as according to equation 1 .

$$
\text { CAPbuf }_{i, t}=\text { CAPtot }_{i, t}-\text { CAPreg }_{i, t}
$$

in which $C A P b u f_{\mathrm{i}, \mathrm{t}}$ is the capital buffer determined by institution $i$, at time $t$, translating the "excess" capital in relation to the regulatory minimum; CAPtot $\mathrm{i}_{\mathrm{i}, \mathrm{c}}$ corresponds to the Basel ratio calculated by institution $i$, at time $t$, with data obtained from the capital information featuring in the IF.data database of the BC; and CAPreg $g_{\mathrm{i}, \mathrm{t}}$ is the value corresponding to the minimum capital requirement of institution $i$, at time $t$, via the application of the " $F$ " factor to the amount of risk weighted assets (RWA), as foreseen in CMN Resolution n. 2,099/1994 and subsequent alterations. 
Having defined the dependent variable of interest, model 2 is specified to test the relationship predicted in hypothesis $\mathrm{H}_{1}$, with the use of panel data, based on the capital structure model of Nier and Baumann (2006), based in turn on Ayuso et al. (2004) and Flannery and Rangan (2004).

$$
\begin{aligned}
\text { CAPbuf }_{i, t}=\beta_{0}+ & \beta_{i}+\beta_{1} \text { MD }_{i, t}+\beta_{2} \text { SIZE }_{i, t}+\beta_{3} \text { ROE }_{i, t}+\beta_{4} \text { RISKcred }_{i, t}+\beta_{5} \text { RISKass }_{i, t} \\
& +\beta_{6} \text { GAP }_{t}+\beta_{7} \text { CRISIS }_{t}+\beta_{8} \text { BASEL }_{t}+\beta_{9} T C_{i}+\varepsilon_{i, t}
\end{aligned}
$$

in which $C A P b u f_{i, t}$ is the capital buffer determined by institution $i$, at time $t$, measured according to equation $1 ; M D_{\mathrm{i}, \mathrm{t}}$ represents the market discipline of institution $i$, in period $t$, alternatively measured by the proxies defined in section 3.2; $\beta_{0}$ and $\beta_{\mathrm{i}}$ are the constant and the crosssectional fixed effects (FE) of the model, respectively; $S I Z E_{\mathrm{i}, \mathrm{t}}$ is the size of institution $i$, in period $t$, defined as the natural logarithm of total assets, with data from the assets series from IF.data of the $\mathrm{BC} ; R O E_{\mathrm{i}, \mathrm{t}}$ is the return on equity of institution $i$, in period $t$, calculated quarterly based on the net profit over average net equity; RISKcred $d_{\mathrm{i}, \mathrm{t}}$ corresponds to the risk of the credit portfolio of institution $i$, in period $t$, defined as the provision for doubtful receivables over the loans portfolio, with data from the asset series of IF.data of the BC; RISKass $\mathrm{i}_{\mathrm{i}, \mathrm{t}}$ is the risk of the bank's assets, with data from the asset series of IF.data of the $\mathrm{BC} ; G A P_{\mathrm{t}}$ is the product gap, corresponding to the difference between the gross domestic product (GDP) and the potential GDP, measured by the quarterly average of the real GDP at market prices, in period $t$, with data obtained from the BC, and applying the Hodrick-Prescott filter; CRISIS $_{\mathrm{t}}$ is a dummy variable that characterizes the Brazilian crisis, assuming 1 for quarters from 2014 to 2017 and 0 for the rest; $B A S E L_{\mathrm{t}}$ is a dummy variable that represents the implementation period of the Basel II and III Accords in Brazil, assuming 1 from the $3^{\text {rd }}$ quarter of
2008 to the $4^{\text {th }}$ quarter of 2017 and 0 for the rest; $T C_{t}$ is a dummy variable, assuming 1 for the institutions with government control capital and 0 for the rest; and $\varepsilon_{\mathrm{i}, \mathrm{t}}$ is the regression error term, assuming normality of the residuals, that is, $\sim \mathrm{N}(0, \sigma 2)$.

Regarding the specification of the model, it should be noted that we chose not to use a dynamic panel to evaluate the effect of persistence, given that: (i) some market discipline variables vary little or do not vary over time, which compromises the use of a dynamic structure that would cause a loss of explanatory power in the study; and (ii) the study follows the methodological path of Nier and Baumann (2006), using the time dimension of the dataset to analyze the expected relationships and eliminating the endogeneity - the lagged variables are used as instruments in the two-stage least squares (TSLS) estimation to mitigate that risk - while it captures the potential correlation between the time and the banks in the error structure.

\subsection{Definition of the Market Discipline Variables}

Among the ways of measuring market discipline discussed in the literature, in this study the proxies described in Table 1 are considered.

Table 1

\begin{tabular}{|c|c|c|c|c|}
\hline Variable & Description & Measurement & Authors & $\begin{array}{l}\text { Expected } \\
\text { Sign }\end{array}$ \\
\hline COST & Cost of fundraising & $\begin{array}{l}\text { Ratio between fundraising expenses and average total } \\
\text { deposits minus the Selic interest rate }\end{array}$ & $\begin{array}{l}\text { Demirgüc-Kunt \& Huizinga (2004) } \\
\text { and Fonseca \& González (2010) }\end{array}$ & + \\
\hline USECrest & $\begin{array}{l}\text { Unsecured deposits - } \\
\text { restricted measure }\end{array}$ & $\begin{array}{c}\text { Ratio between the sum of repo operations, interbank } \\
\text { deposits, and treasury bills and the total volume of } \\
\text { fundraising }\end{array}$ & $\begin{array}{l}\text { Nier \& Baumann (2006) and Bouther } \\
\text { \& Francis (2017) }\end{array}$ & + \\
\hline USECwid & $\begin{array}{l}\text { Unsecured deposits - } \\
\text { wide measure }\end{array}$ & $\begin{array}{l}\text { Ratio between total liabilities minus total deposits } \\
\text { and total liabilities }\end{array}$ & Distinguin \& Rugemintwari (2012) & + \\
\hline$D E B T$ & $\begin{array}{l}\text { Eligible capital debt } \\
\text { instrument }\end{array}$ & $\begin{array}{c}\text { Ratio between the sum of complementary capital and } \\
\text { tier } 2 \text { capital and the risk-weighted assets }\end{array}$ & $\begin{array}{c}\text { Nier \& Baumann (2006) and Silva \& } \\
\text { Divino (2012) }\end{array}$ & + \\
\hline RATING & $\begin{array}{l}\text { Risk classification by } \\
\text { rating agency }\end{array}$ & $\begin{array}{c}\text { Dummy variable, assuming } 1 \text { for entities that, at time } \\
t \text {, have a rating evaluated by Moody's, Standard \& } \\
\text { Poor's, or Fitch Ratings, and } 0 \text { for the rest }\end{array}$ & $\begin{array}{l}\text { Barth et al. (2004) and Nier \& } \\
\text { Baumann (2006) }\end{array}$ & + \\
\hline LISTING & $\begin{array}{l}\text { Main stock exchange } \\
\text { listing }\end{array}$ & $\begin{array}{c}\text { Dummy variable, assuming } 1 \text { for the entities that, } \\
\text { at time } t \text {, are listed on the Brasil, Bolsa, Balcão [B3] } \\
\text { exchange, and } 0 \text { for the rest }\end{array}$ & $\begin{array}{l}\text { Bouther \& Francis (2017) and Nier \& } \\
\text { Baumann (2006) }\end{array}$ & + \\
\hline
\end{tabular}

Variables representative of market discipline and expected signs in the estimation of model 2

Source: Elaborated by the authors. 
Based on the assumption that the capital requirement works as deposit insurance, incentivizing the managers to assume greater risks in an attempt to achieve a particular target return, it can be inferred that external investors ultimately demand higher remuneration from the most capitalized banks (Dewatripont \& Tirole, 1994). To characterize the managers' behavior in minimizing the increased cost of capital, following Demirgüc-Kunt and Huizinga (2004) and Fonseca and González (2010), a cost of fundraising (COST) proxy was created, which represents the average cost of capturing deposits, discounted from the Selic interest rate.

Considering that basis and the prediction of $\mathrm{H}_{1}$, a positive relationship is expected between the capital buffer of Brazilian banks and the market discipline proxy.

Along the same lines, the literature reports that investors or depositors exert the market discipline, reducing the volume of new investments (Martinez Peria \& Schmukler, 2001). For Evanoff and Wall (2000), a variation in unsecured deposits can signal an increase in the risk of an entity. Given the peculiarities of the Brazilian banking sector, in which a significant portion of banks' liabilities is funded through repo operations based on government bonds, interbank deposits, and financial securities with a subordination clause, two market discipline proxies were created (USECrest and USECwid), representative of the share of unsecured liabilities in the composition of banks' sources of funding.

The underlying premise is that a greater share of unsecured deposits in the funding of assets implies a better level of bank capitalization. Therefore, based on the literature analyzed and the prediction of $\mathrm{H}_{1}$, a positive relationship is predicted between the capital buffer and market discipline, measured by unsecured liabilities.

The literature also indicates that the spread on the debt instruments is the most correlated with the bank's risk, with the holders of these instruments being the first to incur losses in the case of discontinuity or default, which consequently exerts strong pressure for the banks to maintain a capital buffer (Distinguin \& Rugemintwari, 2012; Scott, 2014). For Silva and Divino (2012), security holders have the power to monitor and influence banks, as they have more information than the market average, enabling them to run risks in long-term securities, with a relatively low monitoring cost, as well as having contractual permission to exercise an influence over the administration of the institution on special occasions.

Although they are not considered banks' own capital, CMN Resolution n. 4,192/2013 allows for debt instruments to be eligible capital under some conditions, such as loss absorption requirements, subordination clauses, perpetuity, and non-cumulativity of dividends. Thus, the $D E B T$ proxy was created, which represents the share of eligible capital in the funding of the banks' assets, where a positive association is expected with the capital buffer, given the terms of hypothesis $\mathrm{H}_{1}$.

Finally, the literature highlights the exercising of market discipline through disclosure. Nier and Baumann (2006) associated the quality and quantity of an institution's disclosure with it being listed on the main stock exchange, which guarantees a greater degree of requirements for disclosure to the market. In addition, they report the greater quantity of information for the market if the bank has a rating from a credit rating agency, as these have information that is not available, but implicitly captured by the rating. In this study, the variables RATING and LISTING were established as disclosure proxies to represent the actuation of market discipline. Considering that basis and the prediction of $\mathrm{H}_{1}$, a positive association is expected between the capital buffer and market discipline mediated by the RATING and LISTING disclosure proxies.

\subsection{Definition of the Control Variables}

With the aim of ensuring the robustness of the findings, besides the previously described explanatory variables of interest, control variables were added to model 2 . Another aspect that justifies and reinforces the inclusion of those control variables is the need to control the different capital buffer levels between the entities, which may be the result of different incentives, such as size, profitability level, risk policy, and regulatory pressure, among other factors.

The literature highlights that large banks can have capital buffers in accordance with the "too-big-to-fail" assumption, which presupposes the receipt of support from the regulator in the case of difficulties (Bouther \& Francis, 2017; Fonseca \& González, 2010). As a result, smaller banks need to offer higher returns to attract depositors (Afzal, 2015). Taking these aspects into account, the SIZE variable was introduced, where a negative relationship with the capital buffer is expected.

Along the same lines, return on equity (ROE) has a relationship with the capital buffer. For Nier and Baumann (2006), the injection of new capital is more costly and the accumulation of capital depends on internally generated resources, consistent with the theory of hierarchization of the sources of capital (pecking order), according to which profitable banks will find it easier to raise capital through retained earnings. Based on the assumption that profit maximization is the goal of every bank, a positive relationship is expected between the ROE and CAPbuf variables. 
Another aspect highlighted in the literature is that banks' capital is related with the level of risks assumed. For Flannery and Rangan (2004), an ex ante risk measure tends to be associated with greater capital buffers, while, for Ayuso et al. (2004) and Nier and Baumann (2006), an ex post risk measure tends to reduce the capital. Thus, the RISKcred and RISKass variables were added, which represent the risk of the credit portfolio and the total risk of the bank to characterize the ex ante and ex post effects, respectively. The first has a relationship with the bank's main activity, revealing that the better the quality of the credit granted, the greater the capital will be (Afzal, 2015). The second represents all the risks incurred by the institution, reflected in the RWA over total assets, indicating that when that proportion increases, the capital decreases. Based on those studies, a positive and negative relationship is expected between CAPbuf and the RISKcred and RISKass variables, respectively.

Given the need to evaluate whether the economic cycle exerts any effect on the capital held by the entities, the GAP and CRISIS variables were introduced. For Ayuso et al. (2004), the capital buffer and the economic cycle tend to be negatively related. Distinguin and Rugemintwari (2012) report that banks tend to present a reduction in capital in periods of economic growth and an increase in periods of recession. In this study, based on the literature analyzed, a negative relationship is expected between the GAP proxy and CAPbuf. Regarding the CRISIS variable, Bertay et al. (2013) and Elyasiani and Keegan (2017) analyzed whether the market discipline of large banks was impacted by the subprime financial crisis. Oliveira et al. (2011) report that during crises banks suffer from the flight of institutional investors. In this study, following the empirical research, and defining the focus on the Brazilian crisis from 2014 to 2017, it is examined whether the capital buffer changes in times of crisis, with a negative relationship being expected between the CRISIS and CAPbuf variables.

To capture the regulatory effects over the capital buffer, following a suggestion from Silva and Divino (2012), the $B A S E L$ variable was incorporated to capture the effects of Basel II and III in Brazil, characterized by the period from the $3^{\text {rd }}$ quarter of 2008 to the $4^{\text {th }}$ quarter of 2017. According to the literature analyzed and taking into account the focus on improving risks and maintaining the capital levels proposed by Basel II and III, a positive relationship is expected between the BASEL variable and the capital buffer.

Finally, Barth et al. (2001) highlight that government control is negatively related with the bank's stability and performance. Silva and Divino (2012) found that public banks have a smaller capital buffer in relation to their private peers, given the ease of obtaining assistance in the absence of liquidity or the injection of capital when needed. In this context, a negative relationship is expected between the TC variable, representative of the banks under state control, and the capital buffer.

\subsection{Sample Selection}

To carry out the empirical tests, quarterly data from 2001 to 2007 are used, from 193 financial conglomerates and independent institutions operating in the National Financial System (NFS), featuring in the IF.data series of the BC. The identification of the publicly-traded banks was obtained from the Economatica ${ }^{\circledR}$ database. The banks' ratings were extracted from the pages of the credit rating agencies Moody's, Standard \& Poor's, and Fitch Ratings. The GDP data considered in the research were those featuring in the 22109 series of the $\mathrm{BC}$, which represents the quarterly GDP at seasonally-adjusted market prices, from 2001 to 2017.

\section{RESULTS ANALYSIS}

\subsection{Descriptive Statistics}

Initially, given the presence of relevant outliers in the sample, the variables were winsorized at 1 and $99 \%$, following Brooks (2014) and Kothari et al. (2005). Such treatment is warranted, primarily due to the fact that the extreme values are often associated with periods at the start or end of operations or with specific characteristics of the institutions, which causes distortions in relation to the dataset, in the accounting and capital variables used in the model. The results of the descriptive statistics are presented in Table 2. 
Table 2

Descriptive statistics of the variables of model 2

\begin{tabular}{|c|c|c|c|c|c|c|}
\hline Variable & Mean & Median & $\begin{array}{l}\text { Standard } \\
\text { deviation }\end{array}$ & Minimum & Maximum & $\begin{array}{c}\text { Coefficient of } \\
\text { variation }\end{array}$ \\
\hline CAPbuf & 0.270 & 0.093 & 0.565 & 0.003 & 4.176 & 2.093 \\
\hline COST & 0.418 & 0.122 & 1.679 & 0.002 & 14.477 & 4.017 \\
\hline USECrest & 0.231 & 0.141 & 0.250 & 0.000 & 0.992 & 1.082 \\
\hline USECwid & 0.669 & 0.688 & 0.230 & 0.184 & 1.000 & 0.344 \\
\hline$D E B T$ & 0.017 & 0.000 & 0.030 & 0.000 & 0.158 & 1.765 \\
\hline RATING & 0.482 & 0.000 & 0.500 & 0.000 & 1.000 & 1.037 \\
\hline LISTING & 0.197 & 0.000 & 0.398 & 0.000 & 1.000 & 2.020 \\
\hline SIZE & 6.293 & 6.229 & 0.989 & 4.462 & 8.955 & 0.157 \\
\hline$R O E$ & 0.028 & 0.032 & 0.097 & -0.464 & 0.287 & 3.464 \\
\hline RISKcred & 0.062 & 0.042 & 0.076 & 0.000 & 0.476 & 1.226 \\
\hline RISKass & 0.752 & 0.728 & 0.365 & 0.066 & 2.207 & 0.485 \\
\hline GAP & -0.068 & 0.127 & 1.663 & -4.531 & 3.040 & -24.456 \\
\hline CRISIS & 0.235 & 0.000 & 0.424 & 0.000 & 1.000 & 2.092 \\
\hline BASEL & 0.559 & 1.000 & 0.497 & 0.000 & 1.000 & 4.017 \\
\hline$T C$ & 0.088 & 0.000 & 0.283 & 0.000 & 1.000 & 1.082 \\
\hline
\end{tabular}

Note: CAPbuf is the excess capital of the institution in relation to the regulatory minimum; COST is the market discipline proxy representative of the cost of fundraising calculated by the ratio between the fundraising expenses and the average total deposits deducted from the Selic interest rate; USECrest is the market discipline proxy related to the share of unsecured deposits represented by the ratio between the sum of repo operations, interbank deposits, and financial securities and the total funds raised; USECwid is the market discipline that represents the share of unsecured loans calculated by the ratio between total liabilities deducted from total secured deposits and total liabilities; DEBT is the market discipline proxy referring to the share of eligible capital instruments, represented by the sum of complementary capital and tier 2 capital relativized by the risk weighted assets (RWA); RATING is the market discipline proxy that identifies whether the bank has a rating from Moody's, Standard \& Poor's, or Fitch Ratings; LISTING is the market discipline proxy that indicates whether the bank is listed on the Brasil, Bolsa, Balcão [B3] exchange; SIZE is the size of the bank, defined as the natural logarithm of total assets; ROE is the profitability level - return on equity - of the bank; RISKcred is the portfolio risk of the banks calculated by the ratio between the provision for doubtful receivables and the stock of credit operations; RISKass represents the risk of the entity's assets, measured by the ratio between the RWA and total assets; GAP corresponds to the product gap calculated by applying the Hodrick-Prescott filter to the quarterly real mean gross domestic product (GDP) at market prices; CRISIS is the dummy variable indicative of the Brazilian crisis period - 2014 to 2017; BASEL is the dummy variable that represents the period of implementation of Basel II and II in Brazil, as of the $3^{\text {rd }}$ quarter of 2008; and TC is the dummy variable indicating if the bank's capital is controlled by the state.

Source: Elaborated by the authors.

The descriptive statistics initially reveal that the Brazilian banks are, on average, well capitalized, with a median capital buffer ( $C A P b u f)$ - excess in relation to the minimum requirement - in the period higher than $9 \%$, with its high variability standing out, increasing the relevance of using the control variables to isolate the effects of the relationship between market discipline and the capital buffer. It is noted that, despite the volatility of the metric, no negative values were calculated for the variable, which would mean that the bank in question presented a capital ratio below the regulatory minimum.
With relation to the variables representative of market discipline, the COST proxy presents high variability, suggesting that Brazilian banks assume different levels of fundraising cost, depending on the risks and the fundraising mix. The proxies representative of unsecured deposits, USECrest and USECwid, demonstrate that, in more restricted terms, the fundraising represented by repo operations, interbank deposits, and financial securities represent, on average, $23 \%$ of the fundraising in the Brazilian banking market and, in a wider context, the unsecured deposits measured by total fundraising 
minus bank deposits account for around $67 \%$ of the funds raised in the system.

Regarding the proxy measured by the DEBT variable, it was found that the sum of the complementary capital and the tier 2 capital, which represents the debt instruments considered capital, accounts, on average, for $1.7 \%$ of the RWA. Concerning the last two proxies for market discipline, RATING and LISTING, representative of the level of disclosure, the banks classified by ratings agencies and listed on the Brasil, Bolsa, Balcão [B3] exchange represented, on average, 48.2 and $19.7 \%$ of the sample, respectively.

For the control variables used, what draws attention is the fact that the $R O E$ variable, which translates the main performance indicator of the banks, records a high dispersion, with an average quarterly return around 3\% higher than the basic interest rate of the economy, on average, revealing the level of profitability of the system. Regarding the variables representative of ex ante and ex post risk, RISKcred and RISKass, which translate the risk of the credit portfolio and the risk of the assets of the entity, respectively, the statistics reveal that the provision for losses in the credit portfolio represents $6.2 \%$, on average, and the ratio between the RWA (which considers the credit, operational, and market risks) and total assets reaches, on average, $75.2 \%$, revealing that the weighting of risk reduces exposure by around $25 \%$ of assets.

The GAP variable presented a negative mean of $6.8 \%$, meaning that the economy presented signs of cooling (real GDP higher than potential GDP), with it being noted that this is the variable with the highest coefficient of variation. With relation to the three control variables represented by dummies, it is found that the periods identified by CRISIS represent $23 \%$ of the quarters considered in the study; $56 \%$ of the period examined occurred under the regulatory precepts of Basel II and III (BASEL) and 9\% (around 17) of the banks in the sample are state controlled (TC).

\subsection{Robustness Tests}

Prior to estimating model 2, the Im, Pesaran, and Shin (IPS), ADF-Fisher, and PPFisher tests were applied to identify the presence of unit roots in the non-dichotomous series and to verify the fulfillment of the premise of stationarity of the series. The null hypothesis of the presence of a unit root was rejected in nine of the 10 variables tested. For the SIZE variable, that hypothesis was rejected in one of the three tests. However, the risk of spurious regressions is removed both by the results of the other two tests and by the existence of a unit root in only one variable, not compromising the rigor of the estimation (Baltagi, 2008).

Next, with the aim of verifying the existence of a correlation between the explanatory variables that could configure problems of a high degree of multicollinearity, the variance inflation factor (VIF) test was carried out, completely removing the risk of multicollinearity between the series. The indicators are lower than 10, as suggested by Gujarati (2006), and the results are found in Table 3.

Table 3

Results of the variance inflation factor (VIF) test for the variables of the model

\begin{tabular}{|c|c|c|c|c|c|c|c|c|c|c|c|c|}
\hline \multirow{2}{*}{ Variable } & \multicolumn{2}{|c|}{ COST } & \multicolumn{2}{|c|}{ USECrest } & \multicolumn{2}{|c|}{ USECwid } & \multicolumn{2}{|c|}{$D E B T$} & \multicolumn{2}{|c|}{ RATING } & \multicolumn{2}{|c|}{ LISTING } \\
\hline & Test & Coef. & Test & Coef. & Test & Coef. & Test & Coef. & Test & Coef. & Test & Coef. \\
\hline COST & 0.0001 & 1.0718 & & & & & & & & & & \\
\hline USECrest & & & 0.0008 & 1.2696 & & & & & & & & \\
\hline USECwid & & & & & 0.0016 & 1.1637 & & & & & & \\
\hline$D E B T$ & & & & & & & 0.0183 & 1.1081 & & & & \\
\hline RATING & & & & & & & & & 0.0002 & 2.3003 & & \\
\hline LISTING & & & & & & & & & & & 0.0000 & 1.6173 \\
\hline SIZE & 0.0005 & 3.5298 & 0.0005 & 3.2152 & 0.0004 & 3.3769 & 0.0005 & 3.3952 & 0.0001 & 3.4258 & 0.0000 & 2.1664 \\
\hline$R O E$ & 0.0287 & 2.1030 & 0.0264 & 1.8947 & 0.0233 & 1.8290 & 0.0295 & 2.0438 & 0.0167 & 1.5777 & 0.0170 & 1.7213 \\
\hline RISKcred & 0.0313 & 1.5421 & 0.0269 & 1.5051 & 0.0257 & 1.5270 & 0.0276 & 1.5551 & 0.0272 & 2.1181 & 0.0272 & 1.8401 \\
\hline RISKass & 0.0019 & 2.0678 & 0.0018 & 1.8659 & 0.0016 & 1.5827 & 0.0017 & 1.5946 & 0.0006 & 1.6844 & 0.0006 & 2.5053 \\
\hline GAP & 0.0000 & 1.3441 & 0.0000 & 1.1936 & 0.0000 & 1.1793 & 0.0000 & 1.2119 & & & 0.0001 & 2.8026 \\
\hline CRISIS & 0.0002 & 1.9609 & 0.0002 & 1.7611 & 0.0002 & 1.7603 & 0.0002 & 1.8453 & & & & \\
\hline
\end{tabular}


Table 3

Cont.

\begin{tabular}{|c|c|c|c|c|c|c|c|c|c|c|c|c|}
\hline \multirow{2}{*}{ Variable } & \multicolumn{2}{|c|}{ COST } & \multicolumn{2}{|c|}{ USECrest } & \multicolumn{2}{|c|}{ USECwid } & \multicolumn{2}{|c|}{$D E B T$} & \multicolumn{2}{|c|}{ RATING } & \multicolumn{2}{|c|}{ LISTING } \\
\hline & Test & Coef. & Test & Coef. & Test & Coef. & Test & Coef. & Test & Coef. & Test & Coef. \\
\hline BASEL & 0.0003 & 4.3828 & 0.0003 & 3.3537 & 0.0003 & 3.2295 & 0.0003 & 3.7694 & & & & \\
\hline$T C$ & & & & & & & & & 0.0001 & 2.8113 & 0.0001 & 2.8026 \\
\hline
\end{tabular}

Note: COST is the market discipline proxy representative of the cost of fundraising calculated by the ratio between the fundraising expenses and the average total deposits deducted from the Selic interest rate; USECrest is the market discipline proxy related to the share of unsecured deposits represented by the ratio between the sum of repo operations, interbank deposits, and financial securities and the total funds raised; USECwid is the market discipline that represents the share of unsecured loans calculated by the ratio between total liabilities deducted from the total secured deposits and the total liabilities; DEBT is the market discipline proxy referring to the share of eligible capital instruments, represented by the sum of the complementary capital and the tier 2 capital relativized by the risk weighted assets (RWA); RATING is the market discipline proxy that identifies whether the bank has a rating from Moody's, Standard \& Poor's, or Fitch Ratings; LISTING is the market discipline proxy that indicates whether the bank is listed on the Brasil, Bolsa, Balcão [B3] exchange; SIZE is the size of the bank, defined as the natural logarithm of total assets; ROE is the profitability level - return on equity - of the bank; RISKcred is the portfolio risk of the banks calculated by the ratio between the provision for doubtful receivables and the stock of credit operations; RISKass represents the risk of the entity's assets, measured by the ratio between the RWA and total assets; GAP corresponds to the product gap calculated by applying the Hodrick-Prescott filter to the quarterly real mean gross domestic product (GDP) at market prices; CRISIS is the dummy variable indicative of the Brazilian crisis period - 2014 to 2017; BASEL is the dummy variable that represents the period of implementation of Basel II and II in Brazil, as of the $3^{\text {rd }}$ quarter of 2008; and TC is the dummy variable indicating if the bank's capital is controlled by the state.

Source: Elaborated by the authors.

Next, seeking to evaluate whether the presence of individual effects of the banks warrants the use of panel data, the Chow test was carried out, as suggested by Baltagi (2008), indicating that the use of panel data provides a greater volume of information to the model that is the object of study. Based on that, the Hausman test was carried out, aiming to define what the most indicated model would be in the regressions, FE or random effects (RE). The FE model was indicated, given the rejection of the null hypothesis by the presence of a low $\mathrm{p}$-value in all the tests, as according to the data in Table 4.

Table 4

Statistics from the Chow test and Hausman test

\begin{tabular}{ccccccc}
\hline Variable of interest & COST & USECrest & USECwid & DEBT & RATING & LISTING \\
\hline Chow test & 29.2969 & 35.9486 & 30.8523 & 35.5060 & 3.1163 & 3.0354 \\
\hline Prob (F-statistic) & $(0.0000)$ & $(0.0000)$ & $(0.0000)$ & $(0.0000)$ & $(0.0000)$ & $(0.0000)$ \\
\hline Hausman test & 29.2788 & 38.2185 & 56.6912 & 33.7716 & 163.9325 & 160.7593 \\
\hline (p-value) & $(0.0003)$ & $(0.0000)$ & $(0.0000)$ & $(0.0000)$ & $(0.0000)$ & $(0.0000)$ \\
\hline
\end{tabular}

Note: COST is the market discipline proxy representative of the cost of fundraising calculated by the ratio between the fundraising expenses and the average total deposits deducted from the Selic interest rate; USECrest is the market discipline proxy related to the share of unsecured deposits represented by the ratio between the sum of repo operations, interbank deposits, and financial securities and the total funds raised; USECwid is the market discipline that represents the share of unsecured loans calculated by the ratio between total liabilities deducted from the total secured deposits and the total liabilities; DEBT is the market discipline proxy referring to the share of eligible capital instruments, represented by the sum of the complementary capital and the tier 2 capital relativized by the risk weighted assets (RWA); RATING is the market discipline proxy that identifies whether the bank has a rating from Moody's, Standard \& Poor's, or Fitch Ratings; and LISTING is the market discipline proxy that indicates whether the bank is listed on the Brasil, Bolsa, Balcão [B3] exchange.

Source: Elaborated by the authors.

Finally, considering the evidence of autocorrelation in the residuals identified in the Durbin-Watson and Breusch-Godfrey Lagrange multiplier (LM) tests, as according to Table 5 , and with the aim of removing the possible heteroscedasticity problem in the residuals, preliminary tests were carried out with the estimation 
of model 2, using four different methods to deal with those restrictions: (i) TSLS with seemingly unrelated regression (SUR) pooled cross-section weights (PCSE) standard errors; (ii) TSLS with standard errors from the White covariance matrix; (iii) generalized method of moments (GMM) with SUR PCSE standard errors; and (iv) two-stage estimated generalized least squares (EGLS) with SUR PCSE standard errors, which generate robust parameters, assuming the presence of heteroscedasticity and autocorrelation in the residuals.

Table 5

Statistics from the autocorrelation and heteroscedasticity tests of the residuals

\begin{tabular}{ccccccc}
\hline Variable of Interest & COST & USECrest & USECwid & DEBT & RATING & LISTING \\
\hline Durbin-Watson & 0.2911 & 0.2404 & 0.2823 & 0.2436 & 0.2421 & 0.2410 \\
\hline Breusch-Godfrey & 122.8990 & 192.4801 & 168.1458 & 195.0006 & 195.6862 & 196.9286 \\
\hline Prob (F-statistic) & $(0.0000)$ & $(0.0000)$ & $(0.0000)$ & $(0.0000)$ & $(0.0000)$ & $(0.0000)$ \\
\hline
\end{tabular}

Note: COST is the market discipline proxy representative of the cost of fundraising calculated by the ratio between the fundraising expenses and the average total deposits deducted from the Selic interest rate; USECrest is the market discipline proxy related to the share of unsecured deposits represented by the ratio between the sum of repo operations, interbank deposits, and financial securities and the total funds raised; USECwid is the market discipline that represents the share of unsecured loans calculated by the ratio between total liabilities deducted from the total secured deposits and the total liabilities; DEBT is the market discipline proxy referring to the share of eligible capital instruments, represented by the sum of the complementary capital and the tier 2 capital relativized by the risk weighted assets (RWA); RATING is the market discipline proxy that identifies whether the bank has a rating from Moody's, Standard \& Poor's, or Fitch Ratings; and LISTING is the market discipline proxy that indicates whether the bank is listed on the Brasil, Bolsa, Balcão [B3] exchange.

Source: Elaborated by the authors.

\subsection{Estimation of the Model}

When carrying out the empirical tests to reach a conclusion regarding research hypothesis $\mathrm{H}_{1}$, model 2 was estimated with the use of the six proxy variables representative of market discipline highlighted in Table 1, which are the variables of interest in the study. According to the robustness tests highlighted in Section 4.2, the estimations are carried out with the use of panel data, with cross-sectional FE or FE in the period, according to the case, and use of the SUR PCSE standard errors method. Moreover, to address the problems of endogeneity of the variables, the TSLS estimator was used, using the lagged variables themselves as instruments, following Distinguin and Rugemintwari (2012). The results of the estimations are summarized in Table 6.

Table 6

Results of the estimations of model 2, according to the market discipline proxies

\begin{tabular}{|c|c|c|c|c|c|c|}
\hline \multicolumn{7}{|c|}{ Model tested } \\
\hline \multicolumn{7}{|c|}{ CAPbuf $_{i, t}=\beta_{0}+\beta_{i}+\beta_{1} M_{i, t}+\beta_{2}$ SIZE $_{i, t}+\beta_{3}$ ROE $_{i, t}+\beta_{4}$ RISKcred $_{i, t}+\beta_{5}$ RISKass $_{i, t}$} \\
\hline \multicolumn{7}{|c|}{$+\beta_{6} G A P_{t}+\beta_{7} C R I S I S_{t}+\beta_{8} B A S E L_{t}+\beta_{9} T C_{i}+\varepsilon_{i, t}$} \\
\hline \multirow{2}{*}{ Regressors } & \multicolumn{6}{|c|}{ Dependent variable: $C A P b u f$} \\
\hline & $M D=C O S T$ & $M D=U S E C r e s t$ & $M D=U S E C$ wid & $M D=D E B T$ & $M D=R A T I N G$ & $M D=L I S T I N G$ \\
\hline \multirow{2}{*}{ C } & $1.7524^{* * *}$ & $2.3038^{* * *}$ & $2.1053^{* * *}$ & $2.3272^{* * *}$ & $1.6994^{* * *}$ & $1.6693 * * *$ \\
\hline & $(0.0000)$ & $(0.0000)$ & $(0.0000)$ & $(0.0000)$ & $(0.0000)$ & $(0.0000)$ \\
\hline \multirow{2}{*}{ COST } & $0.0186^{* *}$ & & & & & \\
\hline & $(0.0258)$ & & & & & \\
\hline \multirow{2}{*}{ USECrest } & & 0.0336 & & & & \\
\hline & & $(0.2365)$ & & & & \\
\hline \multirow{2}{*}{ USECwid } & & & $0.3179^{* * *}$ & & & \\
\hline & & & $(0.0000)$ & & & \\
\hline \multirow{2}{*}{$D E B T$} & & & & $0.8208^{* * *}$ & & \\
\hline & & & & $(0.0000)$ & & \\
\hline \multirow{2}{*}{ RATING } & & & & & $0.0686^{* * *}$ & \\
\hline & & & & & $(0.0000)$ & \\
\hline
\end{tabular}


Table 6

Cont.

\begin{tabular}{|c|c|c|c|c|c|c|}
\hline \multicolumn{7}{|c|}{ Model tested } \\
\hline \multicolumn{7}{|c|}{ CAPbuf $_{i, t}=\beta_{0}+\beta_{i}+\beta_{1} M_{i, t}+\beta_{2}$ SIZE $_{i, t}+\beta_{3}$ ROE $_{i, t}+\beta_{4}$ RISKcred $_{i, t}+\beta_{5}$ RISKass $_{i, t}$} \\
\hline \multicolumn{7}{|c|}{$+\beta_{6} G A P_{t}+\beta_{7} C R I S I S_{t}+\beta_{8} B A S E L_{t}+\beta_{9} T C_{i}+\varepsilon_{i, t}$} \\
\hline \multirow{2}{*}{ Regressors } & \multicolumn{6}{|c|}{ Dependent variable: CAPbuf } \\
\hline & $M D=C O S T$ & MD=USECrest & $M D=U S E C$ wid & $M D=D E B T$ & $M D=R A T I N G$ & $M D=L I S T I N G$ \\
\hline \multirow{2}{*}{ LISTING } & & & & & & $0.0183^{* * *}$ \\
\hline & & & & & & $(0.0005)$ \\
\hline \multirow{2}{*}{$S I Z E$} & $-0.2149 * * *$ & $-0.2874 * * *$ & $-0.2885^{* * *}$ & $-0.2910^{* * *}$ & $-0.2091 * * *$ & $-0.1963 * * *$ \\
\hline & $(0.0000)$ & $(0.0000)$ & $(0.0000)$ & $(0.0000)$ & $(0.0000)$ & $(0.0000)$ \\
\hline \multirow{2}{*}{$R O E$} & $0.6850^{* * *}$ & $0.6644^{* * *}$ & $0.6200^{* * *}$ & $0.6994^{* * *}$ & $0.8049^{* * *}$ & $0.8222^{* * *}$ \\
\hline & $(0.0001)$ & $(0.0000)$ & $(0.0000)$ & $(0.0000)$ & $(0.0000)$ & $(0.0000)$ \\
\hline \multirow{2}{*}{ RISKcred } & $1.2998^{* * *}$ & $1.0989^{* * *}$ & $1.0514^{* * *}$ & $1.1356^{* * *}$ & $1.6127^{* * *}$ & $1.5948^{* * *}$ \\
\hline & $(0.0000)$ & $(0.0000)$ & $(0.0000)$ & $(0.0000)$ & $(0.0000)$ & $(0.0000)$ \\
\hline \multirow{2}{*}{ RISKass } & $-0.4688 * * *$ & $-0.5887^{* * *}$ & $-0.5811^{* * *}$ & $-0.6025^{* * *}$ & $-0.4333 * * *$ & $-0.4463 * * *$ \\
\hline & $(0.0000)$ & $(0.0000)$ & $(0.0000)$ & $(0.0000)$ & $(0.0000)$ & $(0.0000)$ \\
\hline \multirow{2}{*}{ GAP } & $0.0115^{* * *}$ & $0.0114^{* * *}$ & $0.0107^{* * *}$ & $0.0118^{* * *}$ & & \\
\hline & $(0.0003)$ & $(0.0004)$ & $(0.0019)$ & $(0.0003)$ & & \\
\hline \multirow{2}{*}{ CRISIS } & $-0.0487^{* * *}$ & $-0.0412^{* * *}$ & $-0.0478^{* * *}$ & $-0.0474 * * *$ & & \\
\hline & $(0.0001)$ & $(0.0018)$ & $(0.0007)$ & $(0.0004)$ & & \\
\hline \multirow{2}{*}{ BASEL } & $0.1316^{* * *}$ & $0.1641^{* * *}$ & $0.1735^{* * *}$ & $0.1698^{* * *}$ & & \\
\hline & $(0.0000)$ & $(0.0000)$ & $(0.0000)$ & $(0.0000)$ & & \\
\hline \multirow{2}{*}{$T C$} & & & & & $-0.0894^{* * *}$ & $-0.0944^{* * *}$ \\
\hline & & & & & $(0.0000)$ & $(0.0000)$ \\
\hline N. banks & 162 & 169 & 169 & 169 & 169 & 169 \\
\hline Period & 2001-2017 & 2001-2017 & 2001-2017 & 2001-2017 & 2001-2017 & 2001-2017 \\
\hline $\mathrm{N}^{\circ}$ Obs. & 4.204 & 5.962 & 6.014 & 5.801 & 6.020 & 6.020 \\
\hline $\mathrm{R}^{2}$ & 0.6611 & 0.6768 & 0.6809 & 0.6780 & 0.3284 & 0.3238 \\
\hline Adjusted $\mathrm{R}^{2}$ & 0.6469 & 0.6669 & 0.6713 & 0.6679 & 0.3203 & 0.3157 \\
\hline F statistic & 39.9022 & 58.5482 & 60.2867 & 56.7730 & 36.4224 & 35.5618 \\
\hline Prob (F-stat) & 0.0000 & 0.0000 & 0.0000 & 0.0000 & 0.0000 & 0.0000 \\
\hline
\end{tabular}

Note: CAPbuf is the excess capital of the institution in relation to the regulatory minimum; COST is the market discipline proxy representative of the cost of fundraising calculated by the ratio between the fundraising expenses and the average total deposits deducted from the Selic interest rate; USECrest is the market discipline proxy related to the share of unsecured deposits represented by the ratio between the sum of repo operations, interbank deposits, and financial securities and the total funds raised; USECwid is the market discipline that represents the share of unsecured loans calculated by the ratio between total liabilities deducted from the total secured deposits and the total liabilities; DEBT is the market discipline proxy referring to the share of eligible capital instruments, represented by the sum of the complementary capital and the tier 2 capital relativized by the risk weighted assets (RWA); RATING is the market discipline proxy that identifies whether the bank has a rating from Moody's, Standard \& Poor's, or Fitch Ratings; LISTING is the market discipline proxy that indicates whether the bank is listed on the Brasil, Bolsa, Balcão [B3] exchange; SIZE is the size of the bank, defined as the natural logarithm of total assets; ROE is the profitability level - return on equity - of the bank; RISKcred is the portfolio risk of the banks calculated by the ratio between the provision for doubtful receivables and the stock of credit operations; RISKass represents the risk of the entity's assets, measured by the ratio between the RWA and total assets; GAP corresponds to the product gap calculated by applying the Hodrick-Prescott filter to the real quarterly mean gross domestic product (GDP) at market prices; CRISIS is the dummy variables indicative of the Brazilian crisis period - 2014 to 2017; BASEL is the dummy variable that represents the period of implementation of Basel II and II in Brazil, as of the $3^{\text {rd }}$ quarter of 2008; and TC is the dummy variable indicating if the bank's capital is state-controlled. For the RATING and LISTING variables, which are fixed over time, the estimation was carried out considering, exclusively, the fixed effects (FE) in the period. Although they are not represented here, for the other market discipline variables, models with crosssectional FE and FE in the period were measured, obtaining similar results.

$* * *, * *, *$ level of significance at 1,5 , and $10 \%$, respectively ( $p$-values in parentheses).

Source: Elaborated by the authors. 
The coefficient associated with the COST proxy presented a positive sign that was statistically significant at $1 \%$, in line with the previous findings of the empirical literature, indicating that debtholders punish riskier banks, demanding higher interest rates on new investments (Fonseca \& González, 2010; Nier \& Baumann, 2006). However, the result would contradict the findings of Afzal (2015), who found a negative and significant association between capital adequacy and cost of deposits for the Pakistani banking industry. As highlighted by Fonseca and González (2010), it is perceived that the relationship between market discipline and the capital buffer depends on the location and context, varying according to the specific characteristics of the countries, such as local regulations and the strength of supervision.

Regarding the USECrest proxy, the estimated result was different from expected, although a positive sign was recorded; it did not present relevance in the estimation with cross-sectional FE, which would indicate the rejection of hypothesis $\mathrm{H}_{1}$. The relevance of the repo operations in the indicator can be indicated as justification for the result calculated, as these liabilities, mostly tied to government bonds, work as secured deposits, characterizing moral hazard, according to the empirical literature studied.

Unlike the USECrest variable, the USECwid proxy, as a wider measure of unsecured liabilities, represented by the share of liabilities financed by the total funding market of the banks, presented a positive coefficient that was statistically significant at $1 \%$ with the dependent variable CAPbuf, confirming the presence of market discipline in the Brazilian banks and ratifying the findings of Distinguin and Rugemintwari (2012) and Nier and Baumann (2006).

With relation to the DEBT proxy, a positive and statistically relevant relationship was verified with the dependent variable CAPbuf, configuring the presence of market discipline in the Brazilian banks through the subordinated debt proxy, thus confirming the findings of Nier and Baumann (2006). That result ratifies the understanding of the relevant literature that the holders of eligible capital debt instruments are the first to incur losses in the case of a bank's default (Scott, 2014). However, the findings would contradict the results calculated by Silva and Divino (2012), where for a similar indicator, the estimated coefficient was negative and significant at $10 \%$, indicating that banks that have access to eligible capital instruments maintain a lower excess capital ratio. That aspect can be partly explained by the objective of the research of Silva and Divino (2012), whose focus was to analyze the persistence of excess capital in the Brazilian financial system, through the lagged capital variable, unlike the object of this study.
Finally, regarding the disclosure variables, represented by the market discipline proxies RATING and LISTING, a positive and statistically relevant relationship was observed with the capital buffer for both variables. The findings confirm previous empirical studies that associate the existence of capital buffers as being the result of exposure to more rigorous market discipline, such as those of the Barth et al. (2004), Bouther and Francis (2017), and Nier and Baumann (2006).

In summary, the results corroborate the core hypothesis of the research $\left(\mathrm{H}_{1}\right)$ and they identify the channels through which market discipline is established in the Brazilian banking system: cost of fundraising, unsecured deposits, subordinated debt, and disclosure.

Among the control variables related to the characteristics of the banks, the SIZE proxy, referring to the size of the banks, was shown to be negative and significant at $1 \%$ in all the tests, confirming that bigger banks have smaller capital buffers. The result is consistent with the too-big-to-fail culture, given the experience of economies of scale and diversification of assets, with a wider reach, smoothing the risk perceived by debtholders, as predicted in previous studies (Afzal, 2015; Fonseca \& González, 2010).

Regarding the $R O E$ variable, this was positive and related with the capital buffer in all the estimations, ratifying the findings of Bouther and Francis (2017) and Nier and Baumann (2006), in that the most profitable banks find it easier to internally increase capital generated through retained earnings, with direct reflections in the capital buffer. In contrast, less profitable banks are unable to increase their capital, like their more profitable peers, and present smaller capital buffers.

The RISKcred and RISKass control variables presented positive and negative relationships, respectively, and statistically significant ones, as predicted in the works of Ayuso et al. (2004), Flannery and Rangan (2004), and Nier and Baumann (2006). The GAP variable, characterized by the difference between the real GDP and the potential GDP, was positive and statistically significant in the four estimations carried out, contradicting the findings of Distinguin and Rugemintwari (2012) and Silva and Divino (2012), who found a negative association between the gap and the capital buffer. That result may be explained by the fact that the Brazilian economy presented GDP growth in a large portion of the period analyzed, as verified in the median of the indicator, signaling that the banks hold capital in periods of economic growth to cover the unexpected losses in times of economic recession. 
Also in relation to the macroeconomic effects, it was observed that the CRISIS variable has a negative and significant relationship in the constitution of the capital buffer, which is consistent with the works of Bertay et al. (2013) and Elyasiani and Keegan (2017). Regarding the regulatory aspects, the BASEL dummy variable was positive and statistically significant in the four tests applied, revealing that the entry into effect of Basel II and III brought a certain improvement in the capital buffer, corroborating the findings of Silva and Divino (2012) regarding the implementation period of Basel I (BCBS, 2006).
Finally, the results of the $T C$ variable showed a negative and statistically significant relationship between the type of control and the capital buffer in five of the six estimations carried out. The result is in line with the works of Barth et al. (2001), Nier and Baumann (2006), and de Silva and Divino (2012), ratifying the idea that government management makes these banks hold a smaller capital buffer in relation to their private peers, given the security derived from the ease of obtaining assistance in the case of a lack of liquidity or the possibility of a capital injection, when necessary.

\section{CONCLUSION}

Given the absence of studies about the topic in the Brazilian banking industry, this paper aimed to investigate the presence of market discipline and capital buffers in Brazilian banks, identifying the channel via which that supervision is manifested. For that, data were collected, covering 2001 to 2017, on 193 financial conglomerates and independent institutions operating in the NFS, featured in the IF.data series of the BC.

As the market discipline phenomenon is not directly verifiable by external agents, proxies were created based on the literature analyzed and on the characteristics of the Brazilian banking system, separated into the cost of fundraising, unsecured deposits, subordinated debt, and disclosure categories. In an attempt to verify the effectiveness of the market as a discipliner of risk taking by banks, materialized in the capital buffer, the market discipline measures were correlated with the capital requirement, represented by the excess capital above the regulatory minimum.

It was first observed that, in a highly regulated environment, regulatory capital works as deposit insurance for banks, meaning debtholders consider them riskier and consequently require higher remuneration. In turn, with the aim of balancing in advance that higher cost effect, managers choose assets that offer a higher return associated with the level of risk, increasing the capital buffer, thus confirming the research hypotheses.

The results corroborate the research hypothesis, indicating that market discipline is established in the Brazilian banking sector through the cost of fundraising, unsecured deposits, subordinated debt, and disclosure. This study reinforces previous studies in that market discipline complements minimum capital requirements, serving as an auxiliary mechanism in bank supervision. In light of this, the adoption of measures is recommended to increase the extent of market discipline, especially in the discussions involving the regulatory reforms within the scope of Pillar 3 - Market Discipline.

With relation to the control variables, incorporated with the purpose of improving the empirical evidence related to the variables of interest, evidence was found that the size, the aspect belonging to the too-big-to-fail hypothesis, the ex post risk representing the risk profile of the assets, and the crisis dummy negatively influence the banks' capital buffers. On the other hand, profitability, credit portfolio risk as a determinant variable of the ex ante risk, and the GAP proxy positively influence the banks' capital. The $G A P$ proxy reinforced the understanding that regulatory capital has a counter-cyclical characteristic, as the banks hold capital in periods of economic growth to cover the unexpected losses in times of economic recession.

Moreover, it was found that the implementation of the regulatory adjustments proposed by Basel II (BCBS, 2006) and Basel III (BCBS, 2011) positively influenced the constitution of the banks' capital buffers, which is consistent with the improvement of the aspects related to risk and capital management advocated by the prudential regulations. Regarding the type of control variable, which characterizes the government-controlled banks, a negative relationship was found with the capital buffer, in line with the findings of previous research, given the security that these institutions have, such as ease of obtaining assistance in the case of a lack of liquidity and the possibility of a capital injection, when necessary.

This study contributes to improving the understanding of the dynamics of market discipline in the Brazilian banking industry and to fostering the empirical discussions around the role of that private supervision in promoting the transparency and solidity of the financial system, providing support for policymakers for formulating policies, procedures, and guidelines that support the banking regulations. Moreover, it reinforces the premises 
of Basel II and III that market discipline plays a relevant role in terms of private supervision of banks' actions.

As limitations of the study, we highlight the lack of public availability of some granular data on the banks, which could provide an improvement in the estimation of the market discipline model, and the capital buffer, such as the amount of secured and unsecured deposits and information on the eligible capital instruments issued by the institutions, among others.
Finally, it is worth noting that the models and the variables developed were based on the specificities of the Brazilian banking industry, and so are not directly applicable in another context without suitable adaptations. Therefore, we suggest new studies that test the validity of the models developed and the research hypotheses in other banking markets and tests with other market discipline proxies to validate the evidence obtained here.

\section{REFERENCES}

Afzal, A. (2015). Impact of market discipline on the capital adequacy of banks: Evidence from an emerging economy. The Lahore Journal of Business, 4(1), 61-73.

Ayuso, J., Pérez, D., \& Saurina, J. (2004). Are capital buffers pro-cyclical? Evidence from Spanish panel data. Journal of Financial Intermediation, 13(2), 249-264.

Baltagi, B. H. (2008). Econometric analysis of panel data ( $4^{\text {th }}$ ed.). John Wiley.

Banco Central do Brasil. (2018). Relatório de Estabilidade Financeira. https://www.bcb.gov.br/content/publicacoes/ ref/201810/RELESTAB201810-refPub.pdf

Barth, J. R., Caprio, G., Jr., \& Levine, R. (2004). Bank regulation and supervision. What works best? Journal of Financial Intermediation, 13(2), 25-248.

Barth, J. R., Caprio, G., Jr., \& Levine, R. (2001). The regulation and supervision of banks around the world: A new database [Working Paper]. The World Bank.

Basel Committee on Banking Supervision. (2006). Basel II: International Convergence of Capital Measurement and Capital Standards: A Revised Framework - Comprehensive Version. Bank for International Settlements. http://www.bis.org/publ/ bcbs128.htm

Basel Committee on Banking Supervision. (2011). Basel III: A global regulatory framework for more resilient banks and banking systems - revised version. Bank for International Settlements. http://www.bis.org/publ/bcbs189.htm

Basel Committee on Banking Supervision. (2018). History of the Basel Committee. Bank for International Settlements. https:// www.bis.org/bcbs/history.htm

Belém V. C., \& Gartner, I. R. (2016). Análise empírica dos buffers de capital dos bancos brasileiros no período de 2001 a 2011. Revista Contabilidade \& Finanças, 27(70), 113-124.

Berger, A. N., Herring, R. J., \& Szegö G. P. (1995). The role of capital in financial institutions. Journal of Banking Finance, 19(3-4), 257-276.

Bertay A. C., Demirgüç-Kunt A., \& Huizinga, H. (2013). Do we need big banks? Evidence on performance, strategy and market discipline. Journal of Financial Intermediation, 22(4), 532-558.

Bliss, R. R., \& Flannery M. J. (2001). Market discipline in the governance of US Bank Holding Companies: Monitoring versus influencing. In F. S. Mishkin. Prudential supervision:
What works and what doesn't (pp. 107-146). The University of Chicago Press.

Bouther, R., \& Francis B. W. (2017). Accounting discretion, market discipline and bank behaviour: Some insights from fair value accounting [Working Paper]. Bank of England. https://papers. ssrn.com/sol3/papers.cfm?abstract_id=2920491

Brooks, C. (2014). Introductory econometrics for finance. Cambridge University Press.

Circular BC n. 3,769/2015. (2015). Establishes the methodology for calculating the additional countercyclical portion of core capital, addressed by Resolution n. 4,193, of March $1^{\text {st }}$ of 2013. http://www.lex.com.br/legis_27038840_ CIRCULAR_N_3769_DE_29_DE_OUTUBRO_DE_2015. aspx

Demirgüc-Kunt, A., Huizinga, H. (2004). Market discipline and deposit insurance. Journal of Monetary Economics, 51(2), 375-399.

Dewatripont, M., \& Tirole, J. (1994). The prudential regulation of banks. Massachusetts Institute of Technology Press.

Distinguin, I., \& Rugemintwari C. (2012). The role of market discipline on bank capital buffer: Evidence from a sample of European banks [Working Paper]. Social Science Research Network. https://papers.ssrn.com/sol3/papers.cfm?abstract_ id $=1739690$

Elyasiani, E., \& Keegan J. M. (2017). Market discipline in the secondary bond market: The case of systemically important banks [Working Paper]. Social Science Research Network. https://papers.ssrn.com/sol3/papers.cfm?abstract_id=2934817

Evanoff, D. D., \& Wall L. D. (2000). Subordinated debt as bank capital: A proposal for regulatory reform. Economic Perspectives, 24(2), 40-53.

Flannery, M. J. (1998). Using market information in prudential bank supervision: A review of the U.S. empirical evidence. Journal of Money, Credit and Banking, 30(3), 273-305.

Flannery, M. J. (2001). The faces of market discipline. Journal of Financial Services Research, 20(2), 107-119.

Flannery, M. J., \& Nikolova S. (2003). Market discipline of US financial firms: Recent evidence and research issues. In W. C Hunter, et al. (Orgs.), Market discipline across countries and industries. Massachusetts Institute of Technology Press.

Flannery, M. J., \& Rangan, K. P. (2004). What caused the bank capital build-up of the 1990s? [Working Paper]. Deposit 
Insurance Corporation Center for Financial Research. https:// www.fdic.gov/bank/analytical/cfr/2004/wp2004/2004-03.pdf

Flannery, M. J., \& Sorescu, S. M. (1996). Evidence of bank market discipline in subordinated debenture yields: 1983-1991. The Journal of Finance, 51(4), 1347-1377.

Fonseca, A. R., \& González, F. (2010). How bank capital buffers vary across countries: The influence of cost of deposits, market power and bank regulation. Journal of Banking \& Finance, 34(4), 892-902.

Gilbert, R. A. (1990). Market discipline of bank risk: Theory and evidence. Federal Reserve Bank of St. Louis Review, 72(1), 3-18.

Gujarati, D. N. (2006). Econometria básica (4a. ed.). Campus.

Keeley, M. C., \& Furlong, F. T. (1990). A re-examination of meanvariance analysis of bank capital regulations. Journal Banking Finance, 14, 69-84.

Kothari, S. P., Leone, A. J., \& Wasley, C. E. (2005). Performance matched discretionary accrual measures. Journal of Accounting and Economics, 39(1), 163-197.

Martinez Peria, M. S., \& Schmukler S. L. (2001). Do depositors punish banks for bad behavior? Market discipline, deposit insurance, and banking crises. The Journal of Finance, 56(3), 1029-1051.

Nier, E., \& Baumann, U. (2006). Market discipline, disclosure and moral hazard in banking. Journal of Financial Intermediation, 15(3), 332-361.

Nieto, M. J. (2012). What role, if any, can market discipline play in supporting macroprudential policy [Occasional Paper]. Banco de Espana. https://ssrn.com/abstract=2024918

Oliveira, R. F., Schiozer, R. F., \& Barros, L. A. B. C. (2011). Too big to fail perception by depositors: An empirical investigation [Working Paper]. Departamento de Pesquisa do Banco Central do Brasil.
Pinheiro, F. A. P., Savoia, S. R. F., \& Securato, J. R. (2015). Basileia III: Impacto para os bancos no Brasil. Revista Contabilidade \& Finanças, 26(69), 345-361.

Resolução CMN n. 2,099/1994. (1994). Approves regulations that describe the conditions relating to access to the National Financial System, to minimum capital requirements and adjusted net capital, to the installation of dependences and to the obligation to maintain adjusted net equity at a value compatible with the degree of risk of the asset operations of the financial institutions and other institutions authorized to operate by the Central Bank. https://www.bcb.gov.br/pre/ normativos/res/1994/pdf/res_2099_v1_O.pdf

Resolução CMN n. 4,192/2013. (2013). Describes the methodology for calculating the Reference Equity (RE) https://www.bcb. gov.br/pre/normativos/res/2013/pdf/res_4192_v2_P.pdf

Scott, H. S. (2014). Capital study report: Use of market discipline [Working Paper]. Social Science Research Network. https:// papers.ssrn.com/sol3/papers.cfm?abstract_id=2377036

Silva, M. S., \& Divino J. A. (2012). Determinantes do capital excedente na indústria bancária brasileira. Revista Pesquisa e Planejamento Econômico, 42(2), 261-293.

Tabak, B. M., Li, D. L., Vasconcelos, J. V. L., \& Cajueiro, D. O. (2013). Do capital buffers matter? A study on the profitability and funding costs determinants of the Brazilian banking system [Discussion Paper]. Banco Central do Brasil.

Tabak, B. M., Noronha, A. C., \& Cajueiro, D. O. (2011). Bank capital buffers, lending growth and economic cycle: Empirical evidence for Brazil [Working Paper]. Banking for International Settlements.

Tarullo, D. K. (2008). Banking on Basel: The future of international financial regulation. Peterson Institute for International Economics. https://econpapers.repec.org/bookchap/ iieppress/4235.htm 